\title{
Essays on International Non-market Strategy and the Political Economy of Environmental Regulation
}

\author{
Sanjay Patnaik \\ Ph.D. awarded by Harvard University, Harvard Business School, May 2012
}

One of the largely underexplored research areas in International Business is how the international non-market environment of companies (e.g. regulators, politicians, non-governmental organizations, international organizations) influences firm strategy and performance and particularly how government regulations can enable firms to capture surplus rents. This holds especially true for new climate change regulations that are being introduced in a growing number of countries and regions around the world (e.g. the European Union, Australia, Canada and California). Despite the increasing importance of such regulations and the widely-held expectation that climate change will become one of the most pressing issues for companies, managers and policy makers in the coming decades, there is a lack of understanding of how these environmental programs affect the strategic actions of firms. For my dissertation, I combined my long-standing interest in the importance of the non-market environment for firm strategy with a deep-seated passion for studying the political economy of climate change regulations. Using the European Union Emissions Trading Scheme (EU ETS) as my empirical setting, I examined several unanswered research questions in international non-market strategy and political economy in three distinct dissertation chapters. The EU ETS as the world's largest regulatory program for greenhouse gases is a comprehensive, multinational regulatory experiment that provides the ideal context for my research. All dissertation chapters are empirical studies that use a variety of econometric methodologies and are strongly embedded within prior literature in non-market strategy (e.g. Baron 1995, De Figureido and Silverman 2006, Fisman 2001), international business and economics (e.g. Caves 2007, Kogut 1983, LaPorta et al. 1997) and political economy (e.g. Grossman and Helpman 1994, Mueller 2003, Mitchell and Munger 1991).

\section{The International Non-market Environment and Rent-seeking}

One of the two main focal points of my dissertation is the role the nonmarket environment of a firm plays in its ability to gain a competitive advantage and capture value. While most of the traditional literature in strategy (e.g. McGahan and Porter 1997, Rumelt 1991) has focused on the immediate market environment of companies (e.g. competitors, suppliers, buyers), there is a growing recognition among scholars in international business and strategy that the non-market environment can similarly exert a large influence on firm strategy and performance. The notion that firms and interest groups (e.g. industry associations) engage in targeted efforts to secure rents from non-market actors such as regulators or politicians (i.e. they engage in rent-seeking) stems from previous work in the political economy literature (e.g. Mueller 2003). In my dissertation, I am using this foundation to evaluate how such rent-seeking behavior can allow firms to capture value from their international non-market environment, thereby combining and extending insights from multiple literatures and disciplines. In particular, I am examining the following research questions in the distinct chapters of my dissertation:

1. Can government regulations facilitate market imperfections that allow firms to capture surplus rents and which companies are more likely to exploit such opportunities?

2. What are the main determinants of the ability of firms to capture rents from their non-market environment: country-, industry-, or firm-affiliation?

3. How do country-specific institutional and political characteristics influence the size of rents industry groups can extract from government regulators?

In order to study these questions, I gathered comprehensive data on industrial plants, firms and industries covered by the EU Emissions Trading Scheme (EU ETS).

\section{Climate Change and the EU ETS}

For my research, I decided to focus on the EU ETS as a newly introduced regulatory program for greenhouses gases for several reasons. First, the multinational nature of the program - as it covers all EU member countries - provides the ideal setting for a research study focused on international business and multinational companies. Second, the EU ETS has created a substantial market for emissions permits (i.e. the right to emit 1 ton of $\left(\mathrm{CO}_{2}\right.$ ), worth billions of Euros every year. These emissions permits are distributed by national regulators and represent substantial economic rents at a permit price above zero. As those rents can be captured by firms and interest groups, this type of regulation is well suited for studying my research questions. Finally, climate change regulations 
are being introduced at an increasing rate all around the world and can be expected to have a profound impact on firms and their strategies as they usually affect the whole cost structure for production and distribution. If the relevant price for $\mathrm{CO}_{2}$ emissions created by these regulations is high enough, it provides incentives for the development of environmentally efficient technologies and increased innovation. Despite the growing salience of climate change regulations, however, little scholarly work has examined how those policies affect firm strategy and performance, particularly in an international context. By focusing on this type of government regulation, I seek to improve our understanding in this crucial area of research.

\section{Main insights from my dissertation research}

In the following sections, I will provide an overview of some of the major findings from my dissertation. Due to space constraints, I will not go into details, but would be happy to discuss them further with any interested reader.

\section{A firm's non-market environment provides clear opportunities to capture surplus rents}

My research shows that certain firms are appropriating surplus rents from the EU ETS through targeted rent-seeking efforts and deliberate strategic actions to comply with the program. I demonstrate that government regulations, which are part of a firm's non-market environment, can actually provide firms with strategic opportunities to capture value rather than impose additional costs on companies. Consequently, the traditionally posited, adversarial relationship between regulations and profits does not always have to hold. Firms that consider the compliance with regulatory programs such as the EU ETS as an opportunity and not solely as regulatory burdens are able to recognize them as possible sources for gaining a competitive advantage. One major implication of my findings is that managers who ignore the non-market environment in their strategic decision making will overlook possibilities to improve their firms' performance. Developing successful strategies, particularly on a multinational level, thus requires an integrated approach to strategy that incorporates careful analyses of both the market and non-market environment of a firm (as already theoretically postulated by Baron 1995).

\section{Multinational companies outperform domestic firms in the non- market environment}

I show empirically that MNCs are capturing larger rents from the EU ETS than domestic firms as they are exploiting existing imperfections in the market for emissions permits to engage in arbitraging behavior. Their multinational presence provides them with a larger information network, an increased flexibility for complying with the regulatory pro- gram and it exposes them to a variety of different national EU ETS rules in various member countries. These factors - among others - allow MNCs to recognize and capitalize on strategic opportunities the nonmarket environment offers them more easily.

\section{Industry-efforts and firm-specific capabilities both can increase} rents captured from the non-market environment

Firm-specific capabilities (needed for example to engage successfully in rent-seeking or to exploit existing arbitrage opportunities) play a substantial role in the ability of firms to capture rents from their nonmarket environment (i.e. their non-market performance). However, in addition to those capabilities, coordinated industry-wide rent-seeking efforts (e.g. through industry associations) can further increase those rents. These results demonstrate that industry- and firm-affiliation are complementary and not exclusionary with regard to non-market performance. This finding thereby sheds new light on the sources of performance differences among firms.

\section{The political and institutional environment in a country affects rent-seeking processes}

Another result derived in my dissertation illustrates that country-specific institutional and political characteristics strongly affect the size of rents interest groups can capture within environmental regulation. This finding shows that the political economy of rent-seeking processes should be taken into account when designing and implementing international climate change regulatory regimes. Just as is the case with rent-seeking in more traditional settings (e.g. trade or agricultural policy), environmental policy is highly vulnerable to concerted efforts by interest groups to appropriate rents. Consequently, not accounting for those rent-seeking processes and failing to recognize country-specific factors that make regulators more susceptible to those processes, might undermine the efficacy of the proposed regulations.

\section{Outlook}

My dissertation was a comprehensive first step within my broader research agenda to improve our understanding of the role the international non-market environment plays in firm strategy and firm performance. Due to my novel approach of examining climate change regulations, I expect to continue this research stream in the coming years, further expanding my analyses of greenhouse gas regulations in different national contexts and focusing on additional, different aspects of international non-market strategy and political economy. 


\section{References}

Baron, David P. 1995."Integrated Strategy: Market and Nonmarket Components." California Management Review 37 (2): 47-65.

Caves, Richard. 2007. Multinational Enterprise and Economic Analysis. Third Edition. New York: Cambridge University Press.

De Figueiredo, John M. and Brian S. Silverman. 2006. "Academic Earmarks and the Returns to Lobbying." Journal of Law and Economics 49 (2), (October): 597-626.

Fisman, Raymond. 2001. "Estimating the Value of Political Connections." American Economic Review 91 (4): 1095-1102.

Grossman, Gene and Elhanan Helpman. 1994. "Protection for Sale." American Economic Review 84 (4): 833-850.

Kogut, Bruce. 1983. "Foreign Direct Investment as a Sequential Process." In The Multinational Corporation in the 1980s, edited by Charles Kindleberger and David Andretsch. Cambridge: MIT Press.

La Porta, Rafael, Florencio López-de-Silanes, Andrei Shleifer, and Robert Vishny. 1997."Legal Determinants of External Finance." Journal of Finance 52 (3): 1131-1150.

McGahan, Anita M. and Michael E. Porter. 1997."How Much Does Industry Matter, Really?" Strategic Management Journal 18 (Summer Special Issue): 15-30.

Mitchell, William and Michael Munger. 1991 "Economic Models of Interest Groups: An Introductory Survey." American Journal of Political Science 35 (May): 512-546.

Mueller, Dennis. 2003. Public Choice III. New York: Cambridge University Press.

Rumelt, Richard P. 1991. "How Much Does Industry Matter?" Strategic Management Journal 12 (3): 167-185.

Sanjay Patnaik is an Assistant Professor in Strategic Management and Public Policy at the George Washington University (GWU) School of Business in Washington, DC. He also holds an appointment as a visiting research scholar in the Management Department at the Wharton School, University of Pennsylvania. Sanjay serves on the advisory board for the Initiative for Global Environmental Leadership (IGEL) at Wharton and he earned his Doctorate in Business Administration (Strategy) from Harvard Business School in 2012. Prior to starting at GWU, he was a visiting lecturer and senior fellow in the Management Department at Wharton. 